\title{
Culture of Lactic Acid Bacteria in Natural Environments Based on Dates
}

\author{
Soumia KEDDARI ${ }^{1 *}$, Mokhtaria Yasmina BOUFADI ${ }^{1}$, Meriem MOKHTAR ${ }^{1}$, Djahira HAMED ${ }^{1}$
}

\section{Soumia KEDDARI ${ }^{1, *}$, Mokhtaria Yasmina BOUFADI', Meriem MOKHTAR $^{1}$, Djahira HAMED}

'Laboratory of Beneficial Microorganisms, Functional Foodand Health (LMBAFS), Faculty of Natural Sciences and Life. Abdelhamid Ibn Badis University, Mostaganem, ALGERIA.

\section{Correspondence}

\section{Soumia KEDDAR}

Faculty of Natural Sciences and Life, Abdelhamid Ibn Badis University of Mostaganem, BP 188, Mostaganem 27000, Algeria.

Phone no: +213558 822911

E-mail: soumia.keddari@univ-mosta.dz History

- Submission Date: 31-12-2020;

- Review completed: 21-02-2021;

- Accepted Date: 01-03-2021.

DOI : 10.5530/pj.2021.13.86

Article Available online http://www.phcogj.com/v13/i3

\section{Copyright}

(C) 2021 Phcogj.Com. This is an open access article distributed under the terms of the Creative Commons Attribution 4.0 International license.

\begin{abstract}
Introduction: Lactic acid bacteria are used in the food industry and have restrictive criteria for probiotic potential. The most common growth media used for lactic acid bacteria is de Man, Rogosa, and Sharpe culture medium (MRS). Methods: In this study, three culture media were developed (date powder DP, date core DC and date core associated with lentils $C L$ ) based on locally available plant materials with a low market value to obtain a less expensive culture medium compared to the reference medium MRS for the growth of lactic acid bacteria. Four lactic strains were used (Lactobacillus acidophilus LbA-CECT4529, Lactobacillus plantarum LbP-CECT 748, Bifidobacterium animalis subsp lactis Bb12 and Bifidobacterium bifidum Bb 443). The growth and acidification kinetics of the tested strains were evaluated. The content sugar was determinate with HPLC. Results: All lactic bacteria were able to grow on all culture media, but the best results were obtained with MRS and DP media. No significant difference ( $p<0.05$ ) was observed between DP and MRS medium. The consumption of sugars and proteins in the DP medium was good with all tested bacteria (70.87 to $81.96 \%$ and 71.42 to $80.90 \%$, respectively). After the analysis of sugar content of DP medium before and after fermentation with high-performance liquid chromatography (HPLC), fructose was the only sugar detected $(45.28 \mathrm{\mu g} / \mathrm{ml} \pm 0.24)$. After fermentation, $83 \%$ of fructose was consumed by Bb12. Conclusion: The present data allow us to conclude that date medium promotes the growth of lactic bacteria and can be considered as MRS standard medium substitute.
\end{abstract}

Key words: Dates, MRS, Lactic acid bacteria, Medium, Fermentation.

\section{INTRODUCTION}

Lactic acid bacteria (LAB) are known as facultatively anaerobic, gram-positive bacteria, which primarily metabolize sugar to lactate. LAB mainly get ATP via the glycolytic pathway. The accumulation of too much lactate results in a large decrease in the $\mathrm{pH}$ of the culture media.

LAB constitute a heterogeneous group of bacteria that are naturally found in many types of food, they are also commensals and are present as natural flora of human and animals. These species are predominant in natural microbial vaginal flora and human intestinal microbiota.

$\mathrm{LAB}$ are an important part of the diet and are responsible for the fermentation of food products such as dairy, bread, meat, or vegetable origin ${ }^{3}$. The most common growth media used for lactic acid bacteria is de Man, Rogosa, and Sharpe culture medium.

Date palm (Phoenix dactylifera L.) is the most important crop in arid and semi-arid areas. It plays an important role in the economic and social life of the people of these regions. Several biotechnological processes allow the production of biomass and various metabolites from date. This biomass production forms the basis of many industrial activities: yeast production, yeast production, etc.

Date palm by-products (leaves, trunk, stones, pedicels, etc.) have various uses in the Saharan regions. Date cores, in particular, are used for feeding livestock when they are not simply thrown away. Extensive research has been conducted on the valorization of date cores into activated carbon ${ }^{5}$, feed supplement ${ }^{6}$, citric acid and protein production ${ }^{7}$, and as a traditional drug for its antimicrobial and antiviral properties. ${ }^{8}$

Dates are known for their nutritional value. Although they are rich in certain mineral salts, vitamins, and organic acids, their sugar content makes them premium food. Due to their high carbohydrate content and relatively long storage, dates and date core offer many technological possibilities depending on the treatment to which they are subjected. ${ }^{9}$

The aim of this study is the biovalorization of a low market value product (Mech Dagla variety dates), as well as a food industry waste (dates nuclei) to develop a new and less expensive culture media replacing the conventional MRS for the growth of lactic bacteria.

\section{MATERIALS AND METHODS}

\section{Bacterial strains and culture conditions}

Four lactic bacteria strains were used in this study: Lactobacillus acidophilus LbA-CECT4529, Lactobacillus plantarum LbP-CECT 748 (Complutense University, Madrid, Spanish); Bifidobacterium animalis subsp lactis $\mathrm{Bb} 12$ and Bifidobacterium bifidum Bb 443 (Chr-Hansen, 
laboratory, Danmark). Bacteria cultures were stored at $-80^{\circ} \mathrm{C}$ in MRS broth (Difco laboratories sparks, MD, USA) containing 15\% of glycerol $(\mathrm{w} / \mathrm{v})$. The inoculums were prepared by transferring glycerol stock crop $(100 \mu \mathrm{L})$ of each strain in $10 \mathrm{~mL}$ MRS broth and subsequently incubated under anaerobic conditions at $37^{\circ} \mathrm{C}$ for 24 hours.

\section{Preparation of broth culture media}

Three natural growing media were developed, (DP) based on date powder, (DC) core of date powder, and (CL) lentils and date core powder. Date pulp is washed and is cut into small pieces and dried at $60^{\circ} \mathrm{C}$ for 72 $\mathrm{H}$. After that, dates are ground with a crusher, and sieved with a $250 \mu \mathrm{m}$ diameter sieve. The powder is kept away from moisture. The cores of dates and lentils were dried at $104^{\circ} \mathrm{C}$ for 5 hours, then cooled, grinded, and sieved. The liquid medium DP and DC are obtained by diluting the powder in distilled water $5 \%(\mathrm{w} / \mathrm{v})$. The CL medium is an equal mixture of the two powders, dates cores and lentils at $2.5 \%(\mathrm{w} / \mathrm{v})$ each one. After agitation for $30 \mathrm{~min}$, the solution is centrifuged at $6000 \mathrm{rpm}$ for $10 \mathrm{~min}, \mathrm{pH}$ is adjusted to $6.5 \pm 0.1$ and the solution is autoclaved at $120^{\circ} \mathrm{C}$ for $20 \mathrm{~min}$.

\section{Fermentation procedure of the different cultivated media}

The inoculum was prepared by transferring $10 \mu \mathrm{L}$ of each bacterium culture to $10 \mathrm{~mL}$ of MRS broth and incubated at $37^{\circ} \mathrm{C}$ for $24 \mathrm{~h}$. The cells were collected in a sterile tube $(15 \mathrm{~mL})$ and centrifuged for $10 \mathrm{~min}$ at $6000 \mathrm{rpm}$. The resulting cap was suspended in sterile distilled water to adjust the optical density from 0.08 to 0.10 at $\mathrm{A}_{625}$ which corresponds to $10^{8} \mathrm{cfu} / \mathrm{mL} .^{9}$ The different culture media (DP, DC, and CL) are inoculated with a $1 \%(\mathrm{v} / \mathrm{v})$ of preculture of each strain and incubated at $37^{\circ} \mathrm{C}$ for 72 hours.

\section{Chemical characterization of the culture media before and after fermentation}

\section{Determination of dry matter}

The dry content is determined on an aliquot portion of $5 \mathrm{~g}$ of sample spread in a porcelain capsule and then dried at $103 \pm 2^{\circ} \mathrm{C} .{ }^{10}$

\section{Determination of total sugars}

Total sugars were evaluated according to the method of Dubois. The absorbance was measured at $490 \mathrm{~nm}$ using Jenway-6715 Spectrophotometer (England). ${ }^{11}$

\section{Determination of protein content}

Proteins in the liquid medium were evaluated by the Bradford spectrophotometric method at a wavelength of $595 \mathrm{~nm} .{ }^{12}$

\section{Determination of growth and acidification kinetics}

A sample is collected at the start of the fermentation (0 hours), and after $6 \mathrm{~h}, 12 \mathrm{~h}, 24 \mathrm{~h}, 48 \mathrm{~h}$, and $72 \mathrm{~h}$ to determine the produced biomass and measure the $\mathrm{pH}$.

\section{Bacterial enumeration}

The growth kinetics of beneficial strains of the genera Lactobacilli sp and Bifidobacterium sp were determined by direct enumeration on MRS agar medium. A sample of $50 \mu \mathrm{L}$ of each culture was diluted with a $450 \mu \mathrm{L}$ of MRS both, then a volume of $10 \mu \mathrm{L}$ was taken and cultured In a petri dish containing solid MRS. After incubation at $37^{\circ} \mathrm{C}$ For 48 hours, colonies numbers are calculated using the following formula: $\mathrm{N}=$ $\Sigma$ n colonies. $1000 \mu \mathrm{L} / 30 \mu \mathrm{L}^{13}$

\section{$\mathrm{pH}$ measurements}

The acidity developed in the culture media from the collected samples was assessed by measuring $\mathrm{pH}$ using a potentiometer (Jenway-6715 Spectrophotometer, England).

\section{Sample preparation for high-performance liquid chromatography analysis}

\section{Derivatization of sugars with PMP}

The phenyl-3-methyl-5-pyrazole (PMP) derivatization of monosaccharides was carried out according to the method described by Goubet et al. ${ }^{14}$ Briefly, a sample of $20 \mu \mathrm{L}$ of monosaccharide standards (glucose, fructose, sucrose) or broth samples was mixed with $400 \mu \mathrm{L}$ of $0.3 \mathrm{M}$ aqueous $\mathrm{NaOH}$ and $400 \mu \mathrm{L}$ of $0.5 \mathrm{M}$ PMP-methanol solution. The mixtures were allowed to react at $70{ }^{\circ} \mathrm{C}$ for 30 minutes in a water bath, and then cooled to room temperature and neutralized with $400 \mu \mathrm{L} 0.3$ $\mathrm{M} \mathrm{HCl}$. The resulting solution was separated by liquid-liquid extraction using a volume of chloroform (three times, $2 \mathrm{~mL}$ ). After being shaken vigorously and centrifuged, the organic phase was carefully discarded to remove the excess reagents. Then the aqueous layer was analyzed by HPLC analysis.

\section{HPLC analysis}

The chromatographic analysis was performed on a Thermo Finnigan Surveyor Plus HPLC apparatus equipped with a thermo stated auto sampler (Auto sampler Surveyor Plus), a quaternary pump (Surveyor LC Pump Plus), and a diode-array detector (Surveyor PDA Plus) with a $5 \mathrm{~cm}$ Light Pipe flow cell.

Separations were performed on an Agilent Zorbax carbohydrate column $(250 \times 4.6 \mathrm{~mm}$ I.D., $5 \mu \mathrm{m})$. The mobile phase was composed of acetonitrile-water (80:20) and a flow rate of $1 \mathrm{~mL} / \mathrm{min}$. The injection volume was $5 \mu \mathrm{L}$. The UV spectra were recorded in the range of 200$400 \mathrm{~nm}$ and the DAD was set at $245 \mathrm{~nm}$.

\section{Statistical analysis}

All measurements were repeated 3 times and expressed as means \pm standard deviation. Data were analyzed using statistica ${ }^{\infty}$ (6.0) software. Differences were considered significant when $\mathrm{p}<0.05$.

\section{RESULTS}

\section{Physico-chemical characteristics of liquid culture media before fermentation}

The conventional MRS medium was used as a reference medium for the growth of lactic acid bacteria. The results of the physico-chemical characteristics of each culture media are presented in Table 1.

All culture media $\mathrm{pH}$ was adjusted to 6.50 before sterilization, but after autoclaving at $120^{\circ} \mathrm{C}$ for $20 \mathrm{~min}$, it drops by a few units $(1.12,0.87$, and 0.44 for DP, DC, and CL respectively). MRS pH stayed stable as it contains a buffer solution.

The dry matter content of our media ranges from $8 \%$ to $12 \%$, which is less important than that found in the MRS (13.09\%). For the protein content, DP media has slightly less proteins $(1.12 \mathrm{mg} / \mathrm{mL})$ than MRS does $(1.27 \mathrm{mg} / \mathrm{mL})$. On the other hand, both CL and DC media contain higher levels in proteins (2.48 and 2.06 respectively).

In which concern total sugar, all developed culture medium have a higher content of sugars than the conventional MRS. The amounts of sugars were more important in DP media followed with DC, LC, and finally MRS with levels of $72.1,64.5,40.2$, and $20.4 \mathrm{mg} / \mathrm{mL}$ respectively.

All culture media $\mathrm{pH}$ was adjusted to 6.50 before sterilization, but after autoclaving at $120^{\circ} \mathrm{C}$ for $20 \mathrm{~min}$, it drops by a few units $(1.12,0.87$, and 0.44 for DP, DC, and CL respectively). MRS pH stayed stable as it contains a buffer solution. 
The dry matter content of our media ranges from $8 \%$ to $12 \%$, which is less important than that found in the MRS (13.09\%). For the protein content, DP media has slightly less proteins $(1.12 \mathrm{mg} / \mathrm{mL})$ than MRS does $(1.27 \mathrm{mg} / \mathrm{mL})$. On the other hand, both CL and DC media contain higher levels in proteins ( 2.48 and 2.06 respectively).

In which concern total sugar, all developed culture medium have a higher content of sugars than the conventional MRS. The amounts of sugars were more important in DP media followed with DC, LC, and finally MRS with levels of $72.1,64.5,40.2$, and $20.4 \mathrm{mg} / \mathrm{mL}$ respectively.

\section{Bacterial growth}

The results for the growth kinetics of the four lactic strains used in this experiment are illustrated in Figure 1. According to the results, all developed culture medium were appropriate for the growth of all tested LAB strains.

Although DC and CL culture media had good amounts of sugars and proteins, lactic acid bacteria did not develop very well in this medium compared with the date powder medium (DP).

Bifidobacterium animalis subsplactis $\mathrm{Bb} 12$ had better assimilate the substrates of the four culture media than the rest of lactic bacteria. After $72 \mathrm{~h}$ of incubation, the most important biomass was obtained with the standard medium (MRS) and date powder medium (DP) recording 17.35 and $14.39 \log \mathrm{cfu} / \mathrm{mL}$ respectively. Bifidobacterium bifidum $\mathrm{Bb} 443$ was also able to well developed in the three natural culture media with maximum biomass of $11.89,11.03$, and $9.26 \log \mathrm{cfu} / \mathrm{mL}$ with DP,
$\mathrm{CL}$, and DC. The growth on MRS remains better with $13.03 \log \mathrm{cfu} / \mathrm{mL}$ after $72 \mathrm{~h}$ of incubation.

At the end of fermentation, the growth of both Lactobacillus plantarum LbP-CECT 748 and acidophilus LbA-CECT4529 was similar on the two culture media MRS and DP(12.58 and $11.85 \log$ cfu /mL respectively, $\mathrm{P}=0.106)$.

\section{Determination of acidification kinetics}

In general, the synthesis of organic acids by lactic acid bacteria goes hand in hand with their growth kinetics. The most important organic acid production was obtained with the standard medium (MRS) containing glucose as a source of carbohydrates, followed by DP medium (Figure 2). These results are correlated with the biomass production in both media.

The production of organic acids in date core medium (DC) and the one combined with lentils (CL) were very low compared to MRS and DP media. All tested strains had a slow acidification power in both CL and DC media; therefore, $\mathrm{pH}$ did not drop more than 1.5 units.

After $72 \mathrm{~h}$, no significant difference in $\mathrm{pH}$ was noticed $(\mathrm{p}>0.05)$ in DP and MRS media at the end of fermentation.

\section{Estimated consumption of total sugars and proteins after fermentation}

The quantities of total sugars and proteins consumed by each strain and in the different culture media at the end of the fermentation are

Table 1: Physico-chemical characteristics of culture media.

\begin{tabular}{ccccc} 
Media & $\mathrm{pH}$ & Dry matter(\%) & Proteins $(\mathrm{mg} / \mathrm{mL})$ \\
\hline MRS & $6.50 \pm 0.02$ & 13.09 & $1.27 \pm 0.06$ & Total sugars $(\mathrm{mg} / \mathrm{mL})$ \\
DP & $5.38 \pm 0.1$ & 9.40 & $1.12 \pm 0.04$ & $72.1 \pm 0.06$ \\
DC & $5.63 \pm 0.05$ & 8 & $2.06 \pm 0.03$ & $64.04 \pm 0.06$ \\
CL & $6.06 \pm 0.03$ & 12 & $2.48 \pm 0.02$
\end{tabular}
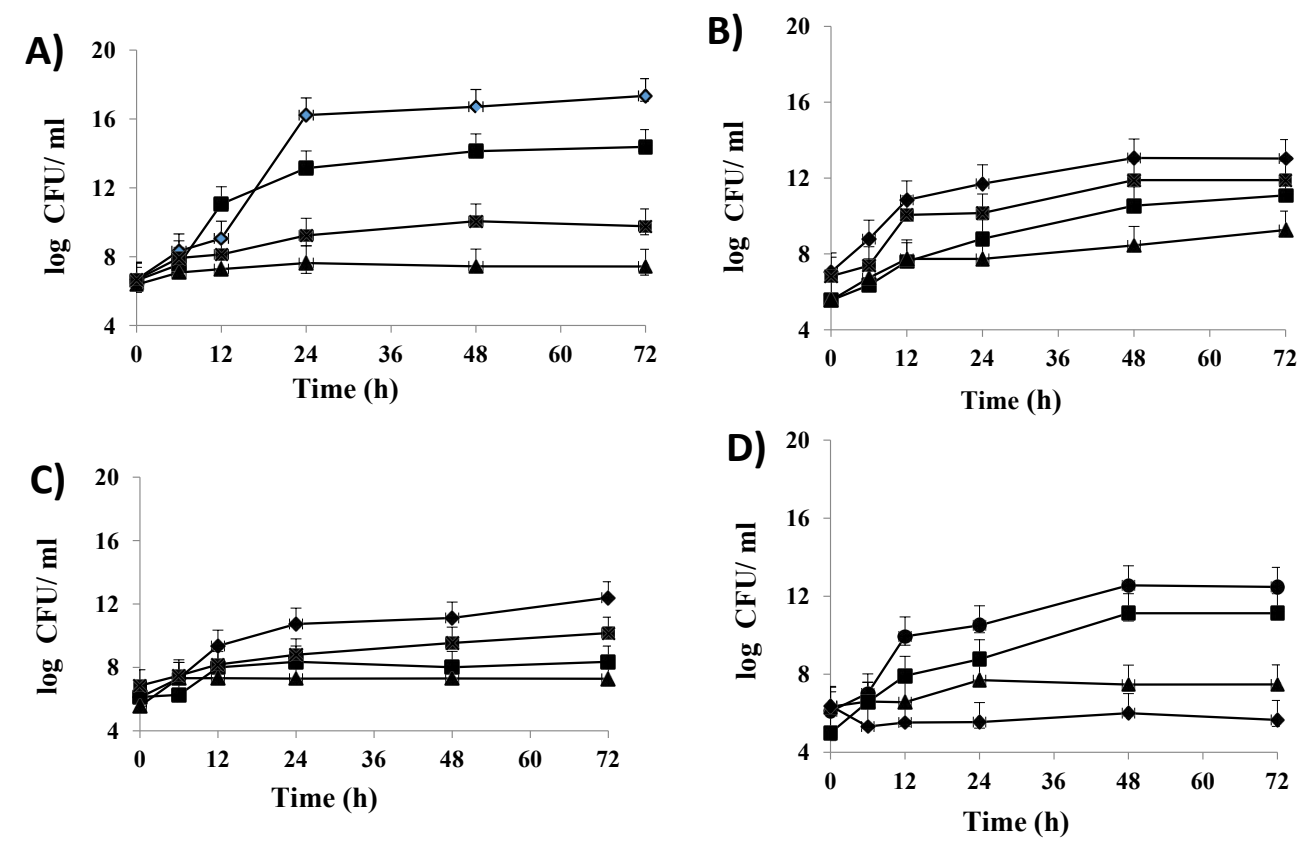

Figure 1: Growth kinetics of LAB strains (A) Bifidobacterium animalis subsp lactis Bb12, (B) Bifidobacterium bifidum Bb443, (C) Lactobacillus acidophilus LbA-CECT4529, (D) Lactobacillus plantarum LbP-CECT 748 monocultivated on complex media based on different substrates (date powder $\square$ DP, date core $\downarrow D C$ with or without lentils $\Delta C L$ ) and in standard medium $\bullet$ MRS. 

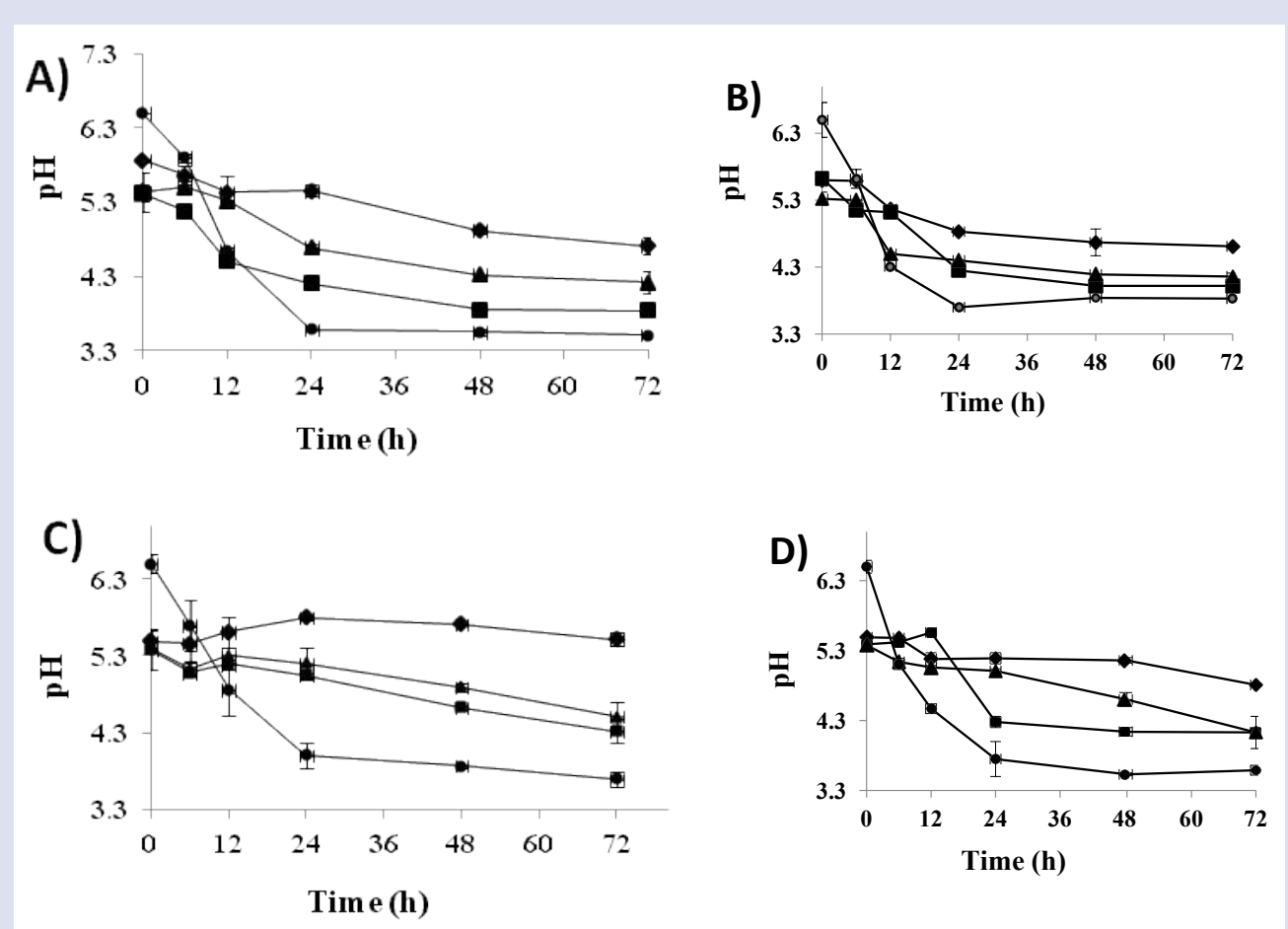

Figure 2: Acidification kinetics of LAB strains (A) Bifidobacterium animalis subsp lactisBb12, (B) Bifidobacterium bifidum Bb443, (C) Lactobacillus acidophilus LbA-CECT4529, (D) Lactobacillus plantarum LbP-CECT 748 monocultivated on complex media based on different substrates (date powder $\mathbf{D} \mathbf{D P}$, date core $\bullet \mathbf{D C}$ with or without lentils $\mathbf{A C L}$ ) and in standard medium $\bullet$ MRS.

Table 2: Total sugars and proteins consumption in fermented culture media.

\begin{tabular}{|c|c|c|c|c|c|}
\hline \multicolumn{2}{|c|}{ Medium } & \multirow{2}{*}{$\begin{array}{c}\text { Quantity in } \\
\text { Total sugar } \\
\text { Consumed } \mathrm{mg} / \mathrm{mL} \\
18.5 \pm 0.1\end{array}$} & \multirow{2}{*}{$\begin{array}{c}\% \text { of total sugar } \\
\text { consumption }\end{array}$} & \multirow{2}{*}{$\begin{array}{c}\begin{array}{c}\text { Quantity in } \\
\text { total protein }\end{array} \\
\text { consumed } \mathrm{mg} / \mathrm{mL} \\
1.01 \pm 0.01\end{array}$} & \multirow{2}{*}{$\begin{array}{c}\text { \%of total protein } \\
\text { consumption }\end{array}$} \\
\hline \multirow{5}{*}{ LbP-CECT 748} & MRS & & & & \\
\hline & DP & $51.1 \pm 0.06^{\mathrm{NS}}$ & 70.87 & $0.80 \pm 0.02^{\mathrm{NS}}$ & 71.42 \\
\hline & CL & $20.2 \pm 0.02^{\star}$ & 50.24 & $1.22 \pm 0.01^{\star}$ & 49.53 \\
\hline & DC & $16.5 \pm 0.08^{\star *}$ & 25.58 & $0.16 \pm 0.01^{\star *}$ & 07.76 \\
\hline & MRS & $18 \pm 0.05$ & 90 & $0.98 \pm 0.02$ & 77.95 \\
\hline \multirow{3}{*}{ LbA-CECT4529 } & DP & $56.1 \pm 0.09^{\mathrm{NS}}$ & 77.80 & $0.82 \pm 0.005^{\mathrm{NS}}$ & 73.79 \\
\hline & CL & $18.2 \pm 0.01^{\star}$ & 45.27 & $1.36 \pm 0.1^{*}$ & 55.12 \\
\hline & DC & $8.5 \pm 0.08^{\star *}$ & 13.17 & $0.19 \pm 0.02^{\star *}$ & 9.22 \\
\hline \multirow{4}{*}{ Bb12 } & MRS & $19.00 \pm 0.05$ & 95 & $1.09 \pm 0.05$ & 85.80 \\
\hline & DP & $59.1 \pm 0.1^{\mathrm{NS}}$ & 81.96 & $0.90 \pm 0.01^{\mathrm{NS}}$ & 80.90 \\
\hline & CL & $20.20 \pm 0.09^{*}$ & 50.24 & $1.46 \pm 0.07^{\star}$ & 58.8 \\
\hline & DC & $13.50 \pm 0.02^{* *}$ & 20.9 & $0.18 \pm 0.04^{\star *}$ & 8.54 \\
\hline \multirow{4}{*}{ Bb443 } & MRS & $19.00 \pm 0.01$ & 95 & $1.06 \pm 0.10$ & 83.48 \\
\hline & DP & $58.10 \pm 0.04^{\mathrm{NS}}$ & 80.58 & $0.89 \pm 0.06^{\mathrm{NS}}$ & 79.46 \\
\hline & CL & $22.20 \pm 0.02^{\star}$ & 55.22 & $1.42 \pm 0.09^{*}$ & 57.25 \\
\hline & DC & $12.50 \pm 0.03^{\star *}$ & 19.47 & $0.19 \pm 0.03^{\star *}$ & 9.22 \\
\hline
\end{tabular}

reported in Table 2. In general, Bb12 remains the strain that consumed the most important quantities of sugars and proteins in all media at the end of fermentation, followed by $\mathrm{Bb} 443$.

At the end of fermentation, both Bifidobacterium strains consumed almost all the sugars (95\%) and more than $83 \%$ of proteins in the MRS medium. In which concerns Lactobacillus, (91 and 90\%) of sugars, and (79 and 78\%) of proteins were consumed by LbP-CECT 748 and LbACECT4529.

Among all developed media, all lactic bacteria had a better consumption of sugars and proteins in DP medium. Values of 81.96 and $80.58 \%$ of sugars were consumed by $\mathrm{Bb} 12$ and $\mathrm{Bb} 443$, respectively. Good protein intake was also noticed with all lactic bacteria in DP medium (71.42 to $80.90 \%)$. DP is a suitable culture media for the growth of LAB. The weakest consumption of both sugars and proteins were observed in the date core medium for all tested strains.

\section{HPLC analysis}

As the date powder culture media was the most interesting among all developed culture media, its monosaccharides profile before and 


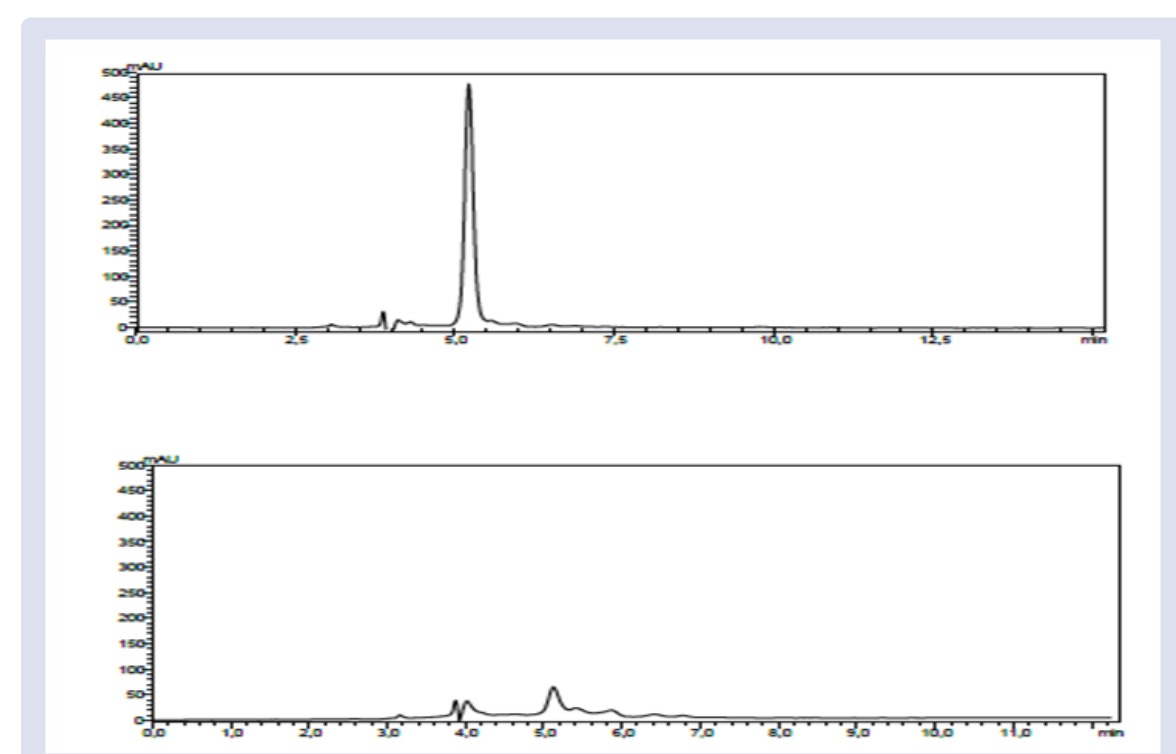

Figure 3: Chromatograms of sugar content in date powder culture medium (DP) broth before (A) and after (B) fermentation (72h) by Bifidobacterium animalis subsp lactis Bb12.

after fermentation was analyzed b HPLC (Figure 3). According to the results only one compound was detected, and by comparison to the retention time of different standard (glucose, fructose, sucrose), this compound corresponds to fructose. After quantification, the amount of fructose was $45.28 \mu \mathrm{g} / \mathrm{ml} \pm 0.24$, but after 72 hours of fermentation, this quantity dropped to $7.68 \mu \mathrm{g} / \mathrm{ml} \pm 0.13$. This means $83 \%$ of fructose was consumed by Bb-12 in date powder medium DP.

\section{DISCUSSION}

The changes in medium $\mathrm{pH}$ during a sterilization process can be explained by changes in medium components. ${ }^{16-17}$ The results of this study are in agreement with the work of Schenk et al. 16 and Vuksanović et al. ${ }^{18}$, the temperature of sterilization can affect media $\mathrm{pH}$ through protein denaturation, carbohydrate hydrolysis, and salt dissolution. This phenomenon was already reported by several studies. ${ }^{19-20-21}$ Natural developed culture media $\mathrm{pH}$ is slightly acidic compared to the MRS medium. As the literature indicates, the optimal $\mathrm{pH}$ for lactic acid bacteria growth is ranged from 4.5 to $6.4 .^{22}$ It is important to highlight that all culture developed media $\mathrm{pH}$ are suitable for the growth of the four tested strains.

According to the literature, dates cores are richer in proteins than the fruit flesh, but despite this, Dates contain essential amino acids that can not be produced by the body and must be supplied in the diet. ${ }^{23}$ Lentils are a rich source of high-quality proteins; it contains approximately $26 \%$ of crude protein. ${ }^{24}$ This can explain how the addition of lentils to date cores has improved the protein content of the newly developed culture media (17\%).

Carbohydrates are predominant components in dates, mainly reducing sugars (glucose and fructose), as well as non-reducing sugars such as sucrose, and small levels of polysaccharides (cellulose and starch). ${ }^{25}$ According to literature, date flesh has a higher content of sugars. ${ }^{26-27}$

Herchi et al. ${ }^{28}$, reported that the flesh of dates contains $83.46 \%$ of total sugars whereas the seeds have $78.69 \%$. This can explain the difference in the total sugar obtained in DP and DC culture medium in present study.

Low growth of LAB in media based in cores (DC and CL) in this study is probably related to antimicrobial activity of cores and not the poverty of the media. ${ }^{28}$ Lactobacilli are able to efficiently use both of the glycolytic pathways facilitates the degradation of a wider range of carbohydrates. ${ }^{29-30}$ According to Huebner et al. ${ }^{31}$, the ability of LAB to metabolize several carbohydrates is related to the intrinsic characteristics of strains and specific substrates, whose degree of polymerization determines the extent of their degradation. Cereals (wheat and oat bran), and their constituents have been reported to stimulate the growth of probiotic lactic strains. ${ }^{32}$

The change of culture media $\mathrm{pH}$ is considered as an indicator of carbohydrates fermentation. This is also the result of the production of organic acids by microorganisms.

These results are consistent with those obtained by several studies. In the presence of complex prebiotic substrates, the $\mathrm{pH}$ of the fermented medium generally decreases by only one $\mathrm{pH}$ unit. ${ }^{33-34}$ This demonstrates the effectiveness of the culture media DP for the growth of lactic bacteria and could be a good replacement for much expensive MRS. The results of the consumption of sugars and proteins reflect the growth of the tested strains in the developed media, where there is a proportional relationship between the assimilation of the substrate and the kinetics of generated growth. Our results are in agreement with those obtained by Thorpe et al. ${ }^{19}$, who found that at kimri and khalal stages the only sugar was fructose. At the rutab stage, the amount of fructose increased sharply; and at the tamer stage fructose was the only sugar detected.

\section{CONCLUSION}

Based on this study, the culture media prepared from date powder (DP) can be considered as an appropriate medium for the growth of lactic acid bacteria and especially Bifidobacterium species. All the tested bacteria demonstrated significantly high growth rate in DP and a good consumption of sugars and proteins during fermentation.

\section{ACKNOWLEDGMENTS}

This work is supported by Ministry of Higher Education and Scientific Research, University Abdelhamid Ibn Badis, Algeria. As part of the Research Project (PRFU). Code: D00L01UN270120190001 « Natural substances of plant and marine origin and therapeutic innovation ». 


\section{DECLARATION OF COMPETING INTERESTS}

The authors declare that there are no known conflicts of interest associated with this publication.

\section{REFERENCES}

1. Kawai M, Harada R, Yoda N. Suppression of lactate production by using sucrose as a carbon source in lactic acid bacteria. J Biosci and Bioengineering. 2020;129(1):47-51.

2. Tailliez, P. Lactobacilli: properties, habitats, physiological role and importance in human health. Antibiotiques. 2004;6(1):35-41.

3. Teusink B, Molenaar D. Systems biology of lactic acid bacteria: For food and Thought. Current Opinion in Systems Biology. 2017;6:7-13.

4. Renschler MA, Wyatt A, Anene N. Using nitrous acid-modified de Man, Rogosa, and Sharpe medium to selectively isolate and culture lactic acid bacteria from dairy foods. J Dairy Sci. 2019;103:1215-22.

5. Alhamed YA. Adsorption kinetics and performance of packed bed adorber for phenol removel using activated carbon from dates stones. J hazard. 2009.

6. Hussein AS, Alhadrami GA. Effect of Enzyme Supplementation and diets containing Date pits on Growth and feed Utilization of Broiler Chicks. Agricultira and Marine Sci. 2003;8(2):67-71.

7. Al-Ogaidi HK, Khalifa, S, Hadi, H, Al-Nakash, S. Production of protein from date stone by Aspergillus Oryzae. J. Water Resour. Res. 1985;4(23):197-206

8. Sabah AA, Jassim A, Naja A. In vitro Evaluation of the Activity of an Extract of Date Palm (Phoenix dactylifera, L.) Pits on a Pseudomons Phage. ECAM. 2007;1:1-6.

9. Eltayeb EA, AL-Hasni, AS, Farooq SA. Changes in soluble sugar content during the development of fruit in some varieties of Omani date palm (Phoenix dactylifera L.). Pakistan J. Biol. Sci. 1999;2:255-8.

10. Kishore GK, Pande S, Podile AR. Biological control of late leaf spot of Peanut (Arachis hypogaea) with chitinolytic bacteria. Phytopathology. 2005;95:1157-65

11. Audigié D, Dupont G, Zonszain T. Manipulation d'analyse biochimique. Ed. Doin. Paris. 1978;pp: 27-74.

12. Dubois M, Gilles KA, Hamilton JK. Colorimetric method for determination of sugars and related substances. Anal. Chem. 1956;28:350-60.

13. Bradford M. A rapid and sensitive method for the quantitation of microgram quantities of protein utilizing the principle of protein-dye binding. J. Analyticol Biochemysty. 1976;72(2):248-54.

14. Guiraud JP. Microbiologie alimentaire. Edition DUNOD Paris France, 2003;431-652.

15. Goubet F, Jackson P, Deery M, Dupree P. Polysaccharie analysis using carbohydrate gel electrophoresis: a method to study plant cell wall polysaccharides and polysaccharide hydrolases. Anal. Biochem. 2002;300:53-68
16. Schenk N, Hsiao KC, Bomman CH. Avoidance of precipitation and carbohydrate breakdown in autoclaved plant tissue culture media. Plant Cell Reports. 1991;10:115-9.

17. Ostrolucka MG, Gajdosova E, Ondruskova A. Effect of medium pH on axillary shoot proliferation of selected Vacciniumvitis-idaea L. Cultivars. Acta Biologica Cracoviensia, Series Botanica. 2010;52(2):92-6.

18. Vuksanović V, Kovačević B, Orlović S, Miladinović D, Kebert M, Katanić M Promene $\mathrm{pH}$ vrednostipodlogeprilikommikropropagacijebeletopole. Topola/Poplar. 2017b;199/200:153-65

19. Thorpe T, Stasolla C, Yeung EC. The components of plant tissue culture media II: organic additions, osmotic and $\mathrm{pH}$ effects, and support systems. In: George EF et al.(ed), Plant propagation by tissue culture, 3rd ed volume 1, the background. (Springer, Dordrecht, The Netherlands). 2008;115-173.

20. Reineke K, Mathys A, Knorr D. Shift of pH-Value During Thermal Treatments in Buffer Solutions and Selected Foods. Inter $\mathrm{J}$ of Food Properties. 2011;14:4,870-81.

21. Chen CC, Bates R, Carlson J. Effect of environmental and cultural conditions in medium $\mathrm{pH}$ and plant growth performance of Douglas-fir (Pseudotsugamenziesii) shoot culture F1000. Research. 2014;3:298.

22. Solval KM, Chouljenko A, Chotiko A, sathivel S. Grouth kinetics and lactic acid production of Lactobacillus plantarum NRRL B-4496, L.acidophilus NRRL B-4495 and L. reutri B-14171 in media containing egg whita hydrolysates. J LWT. 2019;105:393-9.

23. Al-Farsi M, Moris A, Baron M. Functional proprieties of dates (Phoenix dactylifera). Acta Hoticulturae. 2007;736:479-84.

24. Khazaei H, Subedi M, Nickerson M. Seed Protein of Lentils: Current Status. Progress, and Food Applications. 2019; Foods 8:391.

25. Ashraf Z, Hamidi-Esfahani Z. Date and date processing: a review. Food Review International. 2011;27:101-33.

26. Chaira N, Ferchichi A, Mrabet A, Sghairoun M. Chemical composition of the flesh and the pit of date palm fruit and radical scavenging activity of their extracts. Pakistan J. Biol. Sci. 2007;10:2202-7.

27. Ghnimi S, Al-Shiblib M, Al-Yammahib HR. Reducing sugars, organic acids, size, color, and texture of 21 Emirati date fruit varieties (Phoenix dactylifera, L.). NFS J. 2018;12(1):10-25.

28. Herchi W, Arráez-Román D, Trabelsi H. Phenolic compounds in flaxseed: a review of their properties and analytical methods. An overview of the last decade. J Oleo Sci. 2014;63(1):7-14.

29. Yuan X, Wang J, Yao H. Feruloyl oligosaccharides stimulate the growth of Bifidobacterium bifidum. Anaerobes, 2005;11:225-229.

30. O'Donnell MM, O'Toole PW, Ross RP. Catabolic flexibility of mammalian-associated lactobacilli. Microb Cell Fact. 2013;12:48.

31. Huebner J, Wehling RL, Hutkins RW. Functional activity of commercial prebiotics. Inter Dairy J. 2007;17:770-5.

32. Manisseri C, Gudipati M. Bioactive xylooligosaccharides from wheat bran soluble polysaccharides. LWT-Food Sci and Tech. 2010;43:421-30.

33. Madhukumar MS, Muralikrishna G. Structural characterisation and determination of prebiotic activity of purified xylo-oligosaccharides obtained from Bengal gram husk (Cicer arietinum L.) and wheat bran (Triticum aestivum). Food Chemistry. 2010;118:215-23. 


\section{GRAPHICAL ABSTRACT}

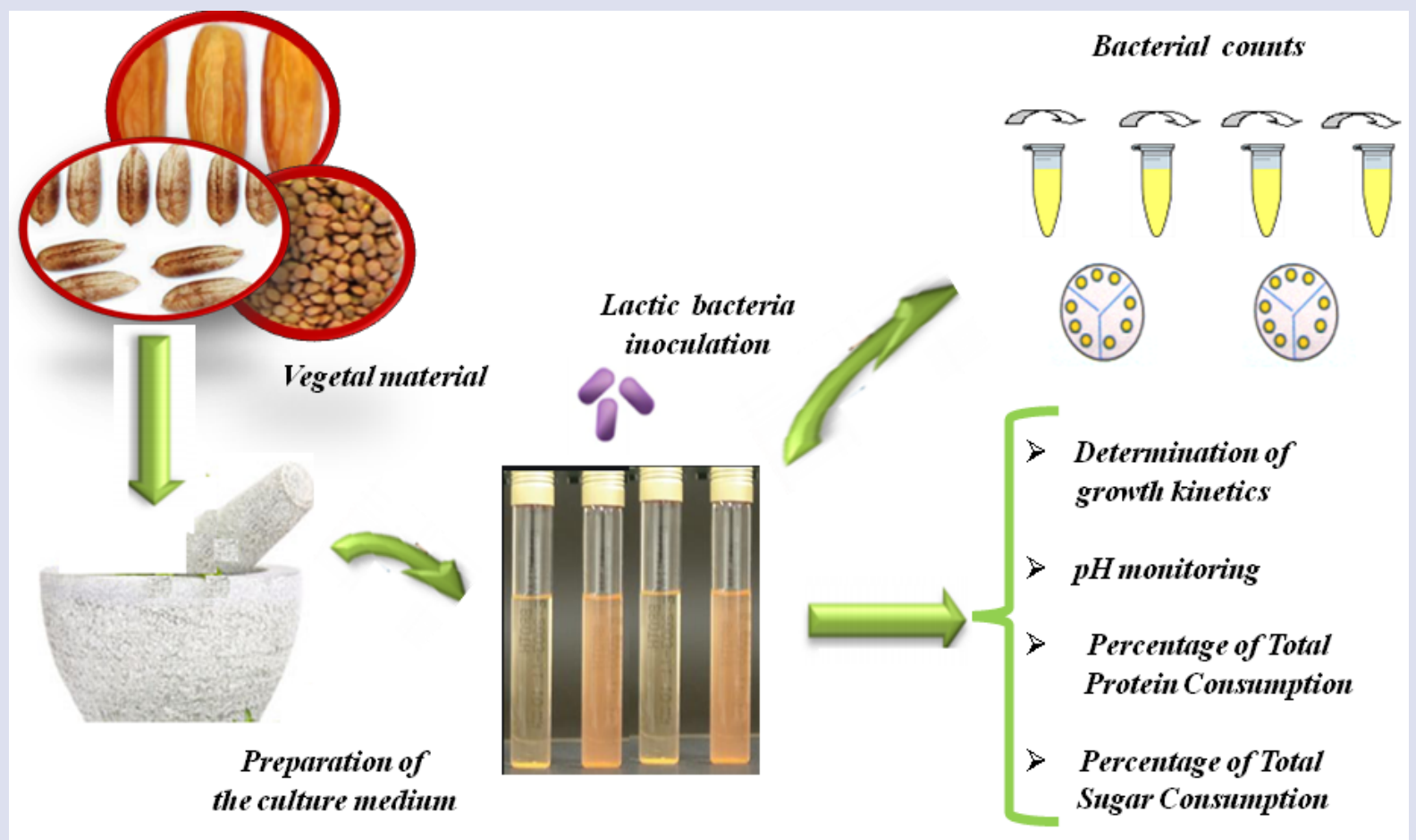

\section{ABOUT AUTHORS}

Dr. Soumia Keddari, born on June 20, 1976 in Mascara, Algeria. Holder of a state engineer diploma in biological sciences (1998) specialization Biological engineering and a doctorate in nutrition (2014). Currently Professor of Nutrition at Abdelhamid Ibn Badis University of Mostaganem and own member at the laboratory of Beneficial Microorganism, Functionnal Food and Health LMBAFS (University of Mostaganem . Dr. Soumia Keddar where team leader on the theme "food and intestinal microbial ecosystems".

Cite this article: KEDDARI S, BOUFADI MY, MOKHTAR M, HAMED D. Culture of Lactic Acid Bacteria in Natural Environments Based on Dates. Pharmacog J. 2021;13(3): 675-81. 